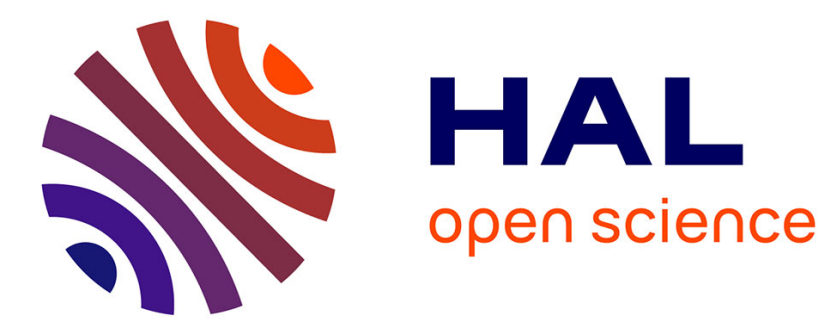

\title{
From Tectons to Composite Crystals
}

Pierre Dechambenoit, Sylvie Ferlay, Mir Wais Hosseini

\section{To cite this version:}

Pierre Dechambenoit, Sylvie Ferlay, Mir Wais Hosseini. From Tectons to Composite Crystals. Crystal

Growth \& Design, 2005, 5 (6), pp.2310-2312. 10.1021/cg058011x . hal-02301495

\section{HAL Id: hal-02301495 \\ https://hal.science/hal-02301495}

Submitted on 25 Nov 2020

HAL is a multi-disciplinary open access archive for the deposit and dissemination of scientific research documents, whether they are published or not. The documents may come from teaching and research institutions in France or abroad, or from public or private research centers.
L'archive ouverte pluridisciplinaire HAL, est destinée au dépôt et à la diffusion de documents scientifiques de niveau recherche, publiés ou non, émanant des établissements d'enseignement et de recherche français ou étrangers, des laboratoires publics ou privés. 


\title{
From tectons to composite crystals
}

\author{
Pierre Dechambenoit, Sylvie Ferlay, Mir Wais Hosseini*
}

Laboratoire de Chimie de Coordination Organique, UMR CNRS 7140, Université Louis Pasteur, F67000 Strasbourg, France

hosseini@chimie.u-strasbg.fr

\section{RECEIVED DATE}

ABSTRACT : A combination of the tecton $1^{2+}$ with $\left[\mathrm{M}^{\mathrm{II}}(\mathrm{CN})_{6}\right]^{4-}(\mathrm{M}=\mathrm{Fe}, \mathrm{Ru})$ complexes anions leads to the formation of analogous 2-D H-bonded networks and isomorphous crystals. Based on the isomorphous nature of the two crystalline systems, the 3-D epitaxial growth of composite crystals upto generation three was achieved and visually demonstrated.

\section{Introduction}

Engineering composite crystals, i.e. growing further crystalline layers on preformed crystals is a topic of current interest because of potential applications in optics and in magnetism for example. To the best of our knowledge, the epitaxial growth of molecular metallo-organic single cocrystals with different composition has been first described by MacDonald et al, ${ }^{1}$ then by Stang $e t a l^{2}$ and finally by us. ${ }^{3}$

The design of composite crystals, ${ }^{1}$ may be achieved through the analysis of information contained in available crystal structures. In particular, by spotting analogies such as isomorphism between crystalline systems, one may imagine procedures leading to the formation of such hierarchical crystalline systems. 
Here we report the formation of a series of composite crystals based on epitaxial growth of crystalline layers on preformed crystals.

During the course of our systematic investigations on the formation of H-bonded molecular networks ${ }^{4}$ between dicationic bisamidinium tectons and di- ${ }^{5}$ tetra-,${ }^{6}$ penta- ${ }^{7}$ and hexa-cyanometallate ${ }^{6,8}$ complex anions, we have noticed that the combination of the same organic tecton such as $\mathbf{1}^{2+}$ (Fig. 1) with cyanometallate anions such as (i) dicyano aurate and argentate, (ii), tetracyano-nickelate, -palladate and -platinate, (iii) hexacyano- ferrate or -cobaltate $\left(\mathrm{M}^{3+}\right)$ and (iv) hexacyano- ferrate or -ruthenate $\left(\mathrm{M}^{2+}\right)$, leads within the same family to isomorphous crystalline materials.

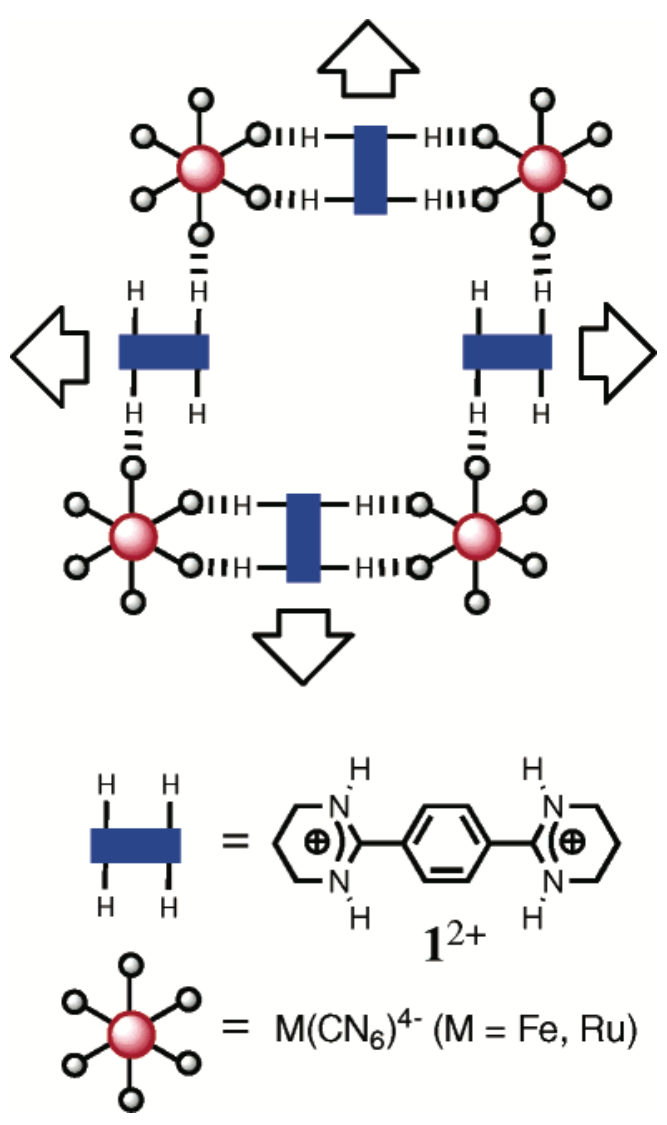

Figure 1. Schematic representation of the 2-D H-bonded network obtained upon combining the dicationic tecton $\mathbf{1}^{2+}$ and hexacyanometallate anions. The arrows represent the translations into two space directions.

In a previous contribution, ${ }^{3}$ we have shown that composite crystals may be obtained using crystals composed of the dicationic tecton $\mathbf{1}^{2+}$ and $\left[\mathrm{M}^{\mathrm{III}}(\mathrm{CN})_{6}\right]^{3-}(\mathrm{M}=\mathrm{Fe}$ or $\mathrm{Co})$ anions. However, although we 
have been able to form the first generation of composite crystals, the crystalline material obtained appeared to be rather fragile and did not allow us to reach the fabrication of higher generations.

\section{Results and discussion}

Structural studies of combinations of the dicationic tecton $\mathbf{1}^{2+}$ with $\left[\mathrm{M}^{\mathrm{II}}(\mathrm{CN})_{6}\right]^{4-}(\mathrm{M}=\mathrm{Fe}$ or $\mathrm{Ru})$ revealed the formation of two analogous 2-D H-bonded networks ${ }^{6,9}$ resulting from the interconnection of octahedral anionic units $\left[\mathrm{M}^{\mathrm{II}}(\mathrm{CN})_{6}\right]^{4-}$ by two dicationic tectons $\mathbf{1}^{2+}$ through both a chelate and a monohapto modes of H-bonding (Fig. 1). Interestingly, both crystals are isomorphous (triclinic, P-1, Z =1) i.e. they present rather close metrics (differences in a $(0.012 \AA)$, b (0.017 $\AA), \mathrm{c}(0.032 \AA)$; $\left.\left(0.008^{\circ}\right), \quad\left(0.02^{\circ}\right), \quad\left(0.05^{\circ}\right)\right) .{ }^{6}$ Further more, the two robust crystalline solids exhibit different colours : whereas $\left[\mathbf{1}^{2+}-\mathrm{Ru}(\mathrm{CN})_{6}{ }^{4-}\right]$ crystals are colourless (Fig. 2a), $\left[\mathbf{1}^{2+}-\mathrm{Fe}(\mathrm{CN})_{6}{ }^{4-}\right]$ crystals are orange (Fig. 2c). We believed that this difference in colour would be appropriate to demonstrate visually the formation of composite crystals. (see table 1)

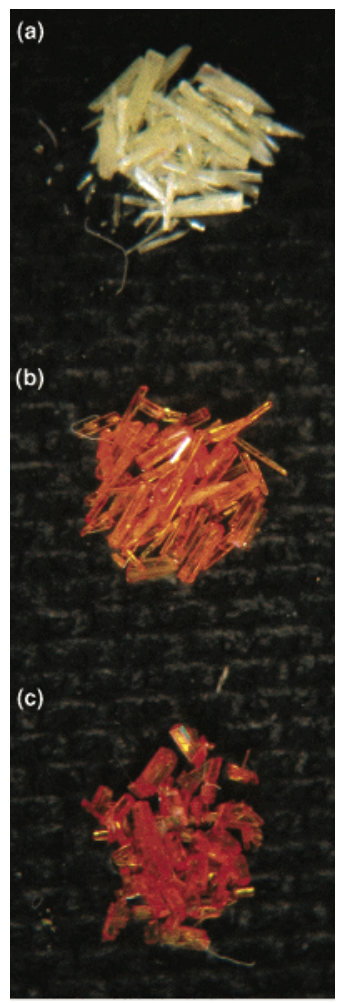

Figure 2. Pictures of crystals of $\left[\mathbf{1}^{2+}-\mathrm{Ru}(\mathrm{CN})_{6}^{4-}\right](\mathrm{a}),\left[\mathbf{1}^{2+}-\mathrm{Fe}(\mathrm{CN})_{6}{ }^{4-}\right]$ (c) and the solid solution obtained upon combining both $\mathrm{Ru}(\mathrm{CN})_{6}{ }^{4-}$ and $\mathrm{Fe}(\mathrm{CN})_{6}^{4-}$ with $\mathbf{1}^{2+}$, with a $1 / 1 \mathrm{Ru}(\mathrm{CN})_{6}{ }^{4-} / \mathrm{Fe}(\mathrm{CN})_{6}^{4-}$ ratio(b).

\begin{tabular}{|l|c|c|c|}
\hline & {$\left[\mathbf{1}^{2+}-\mathrm{Ru}(\mathrm{CN})_{6}{ }^{4-}\right]$} & {$\left[\mathbf{1}^{2+}-\mathrm{Fe}_{0.5} \mathrm{Ru}_{0.5}(\mathrm{CN})_{6}{ }^{4-}\right]$} & {$\left[\mathbf{1}^{2+}-\mathrm{Fe}(\mathrm{CN})_{6}{ }^{4-}\right]$} \\
\hline
\end{tabular}




\begin{tabular}{|c|c|c|c|}
\hline Space group & $\mathrm{P}-1$ & $\mathrm{P}-1$ & $\mathrm{P}-1$ \\
\hline $\mathrm{a}(\AA)$ & $7.6658(2)$ & $7.6598(2)$ & $7.6538(2)$ \\
\hline $\mathrm{b}(\AA)$ & $10.9443(3)$ & $10.9321(3)$ & $10.9276(3)$ \\
\hline $\mathrm{c}(\AA)$ & $13.4958(4)$ & $13.4753(3)$ & $13.4639(3)$ \\
\hline$\left(^{\circ}\right)$ & $70.252(2)$ & $70.256(3)$ & $70.260(5)$ \\
\hline$\left(^{\circ}\right)$ & $75.065(2)$ & $75.080(3)$ & $75.085(5)$ \\
\hline$\left(^{\circ}\right)$ & $85.455(2)$ & $85.463(3)$ & $85.502(5)$ \\
\hline $\mathrm{V}\left(\AA^{3}\right)$ & $1029.63(5)$ & $1026.48(5)$ & $1024.16(4)$ \\
\hline
\end{tabular}

Table 1 : crystallographic parameters of $\left[\mathbf{1}^{2+}-\mathrm{Ru}(\mathrm{CN})_{6}{ }^{4-}\right],\left[\mathbf{1}^{2+}-\mathrm{Fe}(\mathrm{CN})_{6}{ }^{4-}\right]$ and $\left[\mathbf{1}^{2+}-\mathrm{Fe}_{0.5} \mathrm{Ru}_{0.5}(\mathrm{CN})_{6}{ }^{4-}\right]$, recorded at $173 \mathrm{~K}$.

Starting with crystals of $\left[\mathbf{1}^{2+}-\mathrm{Ru}(\mathrm{CN})_{6}{ }^{4-}\right]$ or $\left[\mathbf{1}^{2+}-\mathrm{Fe}(\mathrm{CN})_{6}{ }^{4-}\right]$, considered as generations $\mathrm{G}_{0}(\mathrm{Ru})$ and $\mathrm{G}_{0}(\mathrm{Fe})$ respectively, one could grow the next generation $\left(\mathrm{G}_{1}(\mathrm{Ru}, \mathrm{Fe})\right.$ or $\left.\mathrm{G}_{1}(\mathrm{Fe}, \mathrm{Ru})\right)$ by immersing the preformed crystals $\mathrm{G}_{0}$ into a solution containing the same tecton $\mathbf{1}^{2+}$ and the other cyanometallate anion. In an iterative fashion, one may proceed with crystals of the first generation $\left(G_{1}(R u, F e)\right.$ or $\left.G_{1}(F e, R u)\right)$ and continue the fabrication process to generate the second generation $\left(\mathrm{G}_{2}(\mathrm{Ru}, \mathrm{Fe}, \mathrm{Ru})\right.$ or $\left.\mathrm{G}_{2}(\mathrm{Fe}, \mathrm{Ru}, \mathrm{Fe})\right)$ and further on, by repeating the procedure, one should be able to form the third generation $\left(\mathrm{G}_{3}(\mathrm{Ru}, \mathrm{Fe}, \mathrm{Ru}, \mathrm{Fe})\right.$ or $\left.\mathrm{G}_{3}(\mathrm{Fe}, \mathrm{Ru}, \mathrm{Fe}, \mathrm{Ru})\right)$ etc. (Fig. 3).

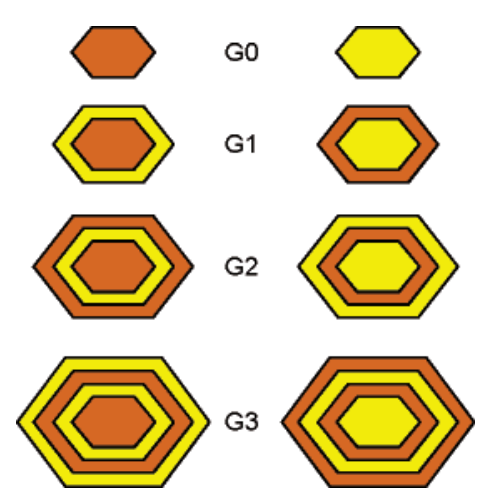

Figure 3. Schematic representation of slices of crystals of crystals generated from the generation $G_{n-1}$ used as seed crystals. The procedure starts with $\mathrm{G}_{0}$ consisting of pure crystals of $\left[\mathbf{1}^{2+}-\mathrm{Ru}(\mathrm{CN})_{6}{ }^{4-}\right]$ or $\left[\mathbf{1}^{2+}-\right.$ 
$\left.\mathrm{Fe}(\mathrm{CN})_{6}{ }^{4}\right]$ and the following generations are obtained, in an iterative fashion, by immersing the crystals of generation $\mathrm{G}_{\mathrm{n}-1}$ into a solution containing tecton $\mathbf{1}^{2+}$ and the other cyanometallate anion.

Both $\mathrm{G}_{0}(\mathrm{Ru})$ and $\mathrm{G}_{0}(\mathrm{Fe})$ crystals were obtained upon slow diffusion of an EtOH solution of $\left[\mathbf{1}^{2+}-2 \mathrm{TsO}^{-}\right]^{10}$ into an aqueous solution of either $\left[\mathrm{K}_{4} \mathrm{Ru}(\mathrm{CN})_{6}\right]$ or $\left[\mathrm{K}_{4} \mathrm{Fe}(\mathrm{CN})_{6}\right]$. Starting with $\mathrm{G}_{0}(\mathrm{Ru})$, the formation of $\mathrm{G}_{1}(\mathrm{Ru}, \mathrm{Fe})$ was achieved by the growth of orange crystalline layers on all faces of the seed crystal. ${ }^{\dagger}$ The composite crystal thus obtained was both visually observed at the macroscopic level and structurally analysed at the microscopic scale by X-ray diffraction. The cutting of the composed crystal clearly demonstrated the growth of orange crystalline system on the colourless seed crystal (Fig. 4a). Interestingly, this microscopic picture shows the same orientation of faces between the seed crystal and the grown crystalline layers. Dealing with the structure of the composite crystal and the orientation of the two crystalline systems, the composite crystal was cutted so as to isolate the colourless and the orange crystalline zones. X-ray diffraction on both isolated crystals demonstrated their identity with the corresponding crystals $\mathrm{G}_{0}(\mathrm{Ru})$ and $\mathrm{G}_{0}(\mathrm{Fe})$. X-ray diffraction on the composite crystal further revealed that the two crystalline systems are oriented in the same space directions. However, some twinned reflections resulting from the slight difference in the cell parameters between the two crystalline systems are observed.

In order to challenge the robustness of the approach, the reverse situation was tested. As expected, again the 3-D epitaxial growth of colourless crystalline layers of $\left[1^{2+}-\mathrm{Ru}(\mathrm{CN})_{6}{ }^{4-}\right]$ on the orange seed crystal $\mathrm{G}_{0}(\mathrm{Fe})$ was achieved (Fig. $\left.4 \mathrm{~b}\right)$. Furthermore, the generality of the process was demonstrated by the repetition of the procedure. Indeed, starting with $\left(\mathrm{G}_{1}(\mathrm{Ru}, \mathrm{Fe})\right.$ or $\mathrm{G}_{1}(\mathrm{Fe}, \mathrm{Ru})$, the second genrations $\mathrm{G}_{2}(\mathrm{Ru}, \mathrm{Fe}, \mathrm{Ru})$ (Fig. 4c) and $\mathrm{G}_{2}(\mathrm{Fe}, \mathrm{Ru}, \mathrm{Fe})$ (Fig. 4d) were obtained. Finally, starting with the latter generation, the third genration crystals of crystals $\mathrm{G}_{3}(\mathrm{Ru}, \mathrm{Fe}, \mathrm{Ru}, \mathrm{Fe})$ (Fig. $\left.4 \mathrm{e}\right)$ and $\mathrm{G}_{3}(\mathrm{Fe}, \mathrm{Ru}, \mathrm{Fe}, \mathrm{Ru})$ (Fig. 4f) were fabricated. 


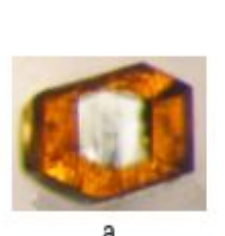

a

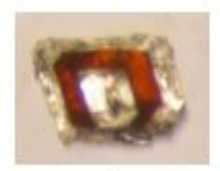

c

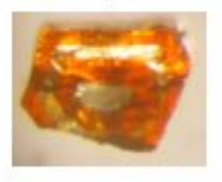

e

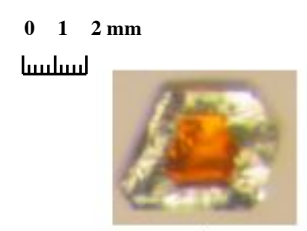

b
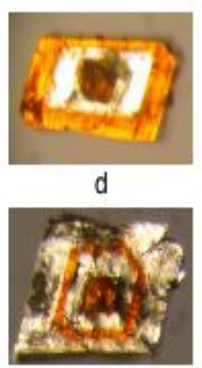

f

Figure 4. Photographs of slices of crystals of crystals of generations $\mathrm{G}_{1}(\mathrm{a}, \mathrm{b}), \mathrm{G}_{2}(\mathrm{c}, \mathrm{d})$ and $\mathrm{G}_{3}(\mathrm{e}, \mathrm{f})$. Colourless and orange zones correspond to $\left[\mathbf{1}^{2+}-\mathrm{Ru}(\mathrm{CN})_{6}{ }^{4-}\right]$ and $\left[\mathbf{1}^{2+}-\mathrm{Fe}(\mathrm{CN})_{6}{ }^{4-}\right]$ crystalline layers respectively.

Whereas the formation of composite crystals is clearly a hierarchical process, we also explored the possibility of forming a crystalline molecular alloy ${ }^{1,2,11}$ or a solid solution resulting from statistical distribution of molecular components in the crystal. As expected, upon slow diffusion of a solution of $\left[\mathbf{1}^{2+}-2 \mathrm{TsO}^{-}\right]$in $\mathrm{EtOH}$ into an aqueous solution containing the potassium salt of both $\mathrm{Fe}(\mathrm{CN})_{6}{ }^{4-}$ and $\mathrm{Ru}(\mathrm{CN})_{6}{ }^{4-}$ anions (1/1 ratio), a crystalline material was indeed obtained. The pale orange colour of the latter (Fig. 2b) is, as expected, intermediate between the colour of $\mathrm{G}_{0}(\mathrm{Ru})$ (colourless, Fig. 2a) and $\mathrm{G}_{0}(\mathrm{Fe})$ (orange, Fig. 2c). Furthermore, for the solid solution, X-ray diffraction revealed intermediate cell parameters between those of $\mathrm{G}_{0}(\mathrm{Ru})$ and $\mathrm{G}_{0}(\mathrm{Fe})$.

In conclusion, we have demonstrated that upon using two isomorphous crystalline systems, based on combinations of the tecton $\mathbf{1}^{2+}$ and $\left[\mathrm{M}(\mathrm{CN})_{6}{ }^{4-}\right](\mathrm{M}=\mathrm{Fe}$ or $\mathrm{Ru})$ anions leading to the formation 2-D Hbonded molecular networks, one may fabricate crystalline multilayered solids, also called composite crystals. The robustness of the approach was demonstrated by generating composite crystals up to the third generation. The formation of such hierarchical crystalline materials based on magnetic or fluorescent crystalline layers is currently under investigation.

\section{Experimental section}


Single crystals of $\left[\left(\mathbf{1}^{2+}\right)-\left(\mathrm{Fe}(\mathrm{CN})_{6}{ }^{4-}\right) \cdot 8 \mathrm{H}_{2} \mathrm{O}\right]$ (orange) and $\left[\left(\mathbf{1}^{2+}\right)-\left(\mathrm{Ru}(\mathrm{CN})_{6}{ }^{4-}\right) \cdot 8 \mathrm{H}_{2} \mathrm{O}\right]($ colourless $)$ were obtained as previously described. ${ }^{6}$

A colourless crystal of $\left[1^{2+}-\left(\mathrm{Ru}(\mathrm{CN})_{6}{ }^{4-}\right]\right.$ (approximately $\left.0.1 \times 0.06 \times 0.02 \mathrm{~mm}\right)$ was glued on a nylon wire before it was immersed or seeded on the surface of an aqueous solution $(2 \mathrm{~mL})$ containing $\mathrm{K}_{4} \mathrm{Fe}(\mathrm{CN})_{6}(2.5 \mathrm{mM})$ and the ditosylate salt of $\mathbf{1}^{2+}(5 \mathrm{mM})$. After one week, in addition to few orange crystals formed in solution corresponding to $\left[\mathbf{1}^{2+}-\left(\mathrm{Fe}(\mathrm{CN})_{6}{ }^{4-}\right]\right.$, a 3-D epitaxial growth of orange crystalline layer on the surface of the seed crystals was observed. The same procedure was repeated starting with orange crystals $\left[\mathbf{1}^{2+}-\left(\mathrm{Fe}(\mathrm{CN})_{6}{ }^{4-}\right]\right.$ as seeds and an aqueous solution containing $\mathrm{K}_{4} \mathrm{Ru}(\mathrm{CN})_{6}$ $(0.8 \mathrm{mM})$ and the ditosylate salt of $\mathbf{1}^{2+}(1.6 \mathrm{mM})$. Again, in addition to colourless crystals corresponding to $\left[1^{2+}-\left(\mathrm{Ru}(\mathrm{CN})_{6}^{4-}\right]\right.$ formed in solution, a colourless crystalline layer was grown on all faces of the orange seed crystals. The same procedure was repeated for the fabrication of generations $\mathrm{G}_{2}$ and $\mathrm{G}_{3}$.

ACKNOWLEDGMENT. Université Louis Pasteur, Institut Universitaire de France, the Ministry of Education and Research and CNRS are acknowledged for financial support. Thanks to J-M. Planeix and N. Kyritsakas for X-ray diffraction studies.

\section{REFERENCES.}

(1) MacDonald, J. C.; Dorrestein, P. C.; Pilley, M. M.; Foote, M. M.; Lundburg, J. L.; Henning, R. W.; Schultz, A. J.; Manson, J. L.; J. Am. Chem. Soc., 2000, 122, 11692-11702; Luo, T-J. M.; MacDonald, J. C.; Palmore, G. T. R. Chem. Mater., 2004, 16, 4916-4927.

(2) Noveron, J.C.; Lah, M. S.; Del Sesto, R. E.; Arif, A. M.; Miller, J. S.; Stang, P. J. J. Am. Chem. Soc., 2002, 124, 6613-6625.

(3) Ferlay, S.; Hosseini, M. W. Chem. Comm., 2004, 788-789.

(4) Hosseini, M. W. Cryts. Eng. Comm., 2004, 6, 318-322. 
(5) Paraschiv, C.; Ferlay, S.; Hosseini, M. W.; Bulach, V.; Planeix, J.-M. Chem. Comm., 2004, $2270-2271$.

(6) Ferlay, S.; Bulach, V.; Félix, O.; Hosseini, M. W.; Planeix, J.-M.; Kyritsakas, N. Cryst. Eng. Comm, 2002, 4, 447-453.

(7) Ferlay, S.; Holakovsky, R.; Hosseini, M. W.; Planeix, J.-M.; Kyritsakas, N. Chem. Comm, 2003, 1224-1225.

(8) Ferlay, S.; Félix, O.; Hosseini, M. W.; Planeix, J.-M.; Kyritsakas, N. Chem. Comm., 2002, $702-$ 703.

(9) Hosseini, M. W. Coord.Chem. Rev., 2003, 240, 157-166.

(10) Félix, O.; Hosseini, M. W.; De Cian, A.; Fischer, J. New J. Chem., 1997, 21, 285-288.

(11) Braga, D.; Cojazzi, G.; Paolucci, D.; Grepioni, F. Chem. Comm., 2001, 803-804.

SYNOPSIS TOC. A combination of the tecton $\mathbf{1}^{2+}$ with $\left[\mathrm{M}^{\mathrm{II}}(\mathrm{CN})_{6}\right]^{4-}(\mathrm{M}=\mathrm{Fe}, \mathrm{Ru})$ complexes anions leads to the formation of analogous 2-D H-bonded networks and isomorphous crystals. Based on the isometric nature of the two crystalline systems, the 3-D epitaxial growth of composite crystals upto generation three was achieved and visually demonstrated.

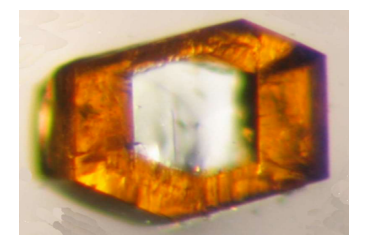

